\title{
The effect of sodium butyrate as a histone deacetylase inhibitor on the gene expression of Bid in HT-29 human colorectal cancer cell line
}

\author{
Najmeh Amiri, ${ }^{1}$ Flora Forouzesh ${ }^{1}$, Ehsan Nazemalhosseini- Mojarad ${ }^{2}$, Mahdi Shabani \\ ${ }^{1}$ Department of Genetics, Faculty of Advanced Science and Technology, Tehran Medical Sciences, Islamic Azad \\ University, Tehran, Iran \\ ${ }^{2}$ Department of Cancer, Gastroenterology and Liver Disease Research Center, Research Institute for Gastroenterology \\ and Liver Diseases, Shahid Beheshti University of Medical Sciences, Tehran, Iran \\ ${ }^{3}$ Department of Immunology, School of Medicine, Shahid Beheshti University of Medical Sciences, Tehran, Iran
}

\begin{abstract}
Background: Sodium butyrate $(\mathrm{NaBr})$, a histone deacetylase inhibitor, has emerged as a promising anticancer drug for multiple cancers. The aim of this study was to investigate the effect of sodium butyrate on the changes in the expression of the Bid gene in human colorectal cancer cell line.

Materials and methods: HT-29 cell line was cultured. Cells were treated with different concentration of $\mathrm{NaBr}$ (from $6.25 \mathrm{mM}$ to $200 \mathrm{mM}$ ) for 24,48 and 72 hours. Cytotoxicity and $\mathrm{IC}_{50}$ were evaluated by MTT assay. The effect of $\mathrm{NaBr}$ on Bid gene expression was examined by PCR and qRT-PCR.

Results: The $\mathrm{IC}_{50}$ for 24,48 , and 72 hours were $95 \mathrm{mM}, 25 \mathrm{mM}$ and, $12.5 \mathrm{mM}$ respectively. Antiproliferative activity of $\mathrm{NaBr}$ was dependent on time and dose manner. The results of real time PCR showed that the expression of Bid gene in treated cells with $\mathrm{IC}_{50}$ concentration increased significantly $(\mathrm{p}<0.05)$ in comparison with the control group.

Conclusion: The results showed that $\mathrm{NaBr}$ inhibited the growth and induced apoptosis in the HT-29 cell line which can be due to the increase in Bid gene expression. So, the change in expression of the apoptosis genes can effect by histone deacetylase inhibitors.
\end{abstract}

Keywords: Colorectal cancer, Bid gene, Sodium butyrate, HT-29.

Cited as: Amiri N, Forouzesh F, Nazemalhosseini- Mojarad E, Shabani M. The effect of sodium butyrate as a histone deacetylase inhibitor on the gene expression of Bid in HT-29 human colorectal cancer cell line. Medical Science Journal of Islamic Azad University, Tehran Medical Branch 2020; 30(1): 40-50.

Correspondence to: Flora Forouzesh

Tel: +9822006660

E-mail: f8forouzesh@gmail.com

ORCID ID: 0000-0002-2747-3479

Received: 23 Jan 2019; Accepted: 28 May 2019 
مجله علوم يزشكى دانشگاه آزاد اسلامى

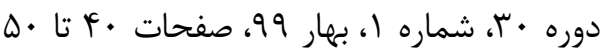

Original

Article

\section{اثر سديم بوتيرات به عنوان مهار كننده هيستون داستيلاز بر روى تغيير بيان زن Bid}

\section{نجمه اميرى'، فلورا فروزش'، احسان ناظم الحسينى -مجرد'، مهدى شعبانى '}

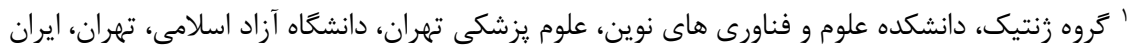

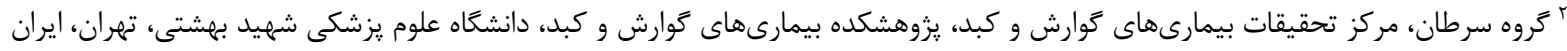

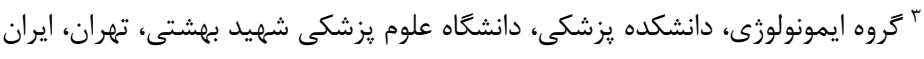
جـكيده سابقه و هدف: سديم بوتيرات (NaBr) مهار كننده هيستون داستيلاز /ست كه به عنوان داروى ضدسرطان اميدبخشى براى درمان

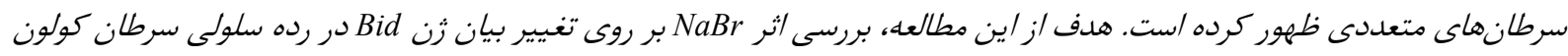
انسانى /ست.

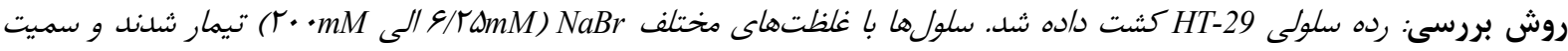

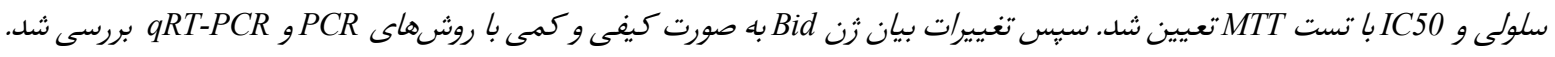

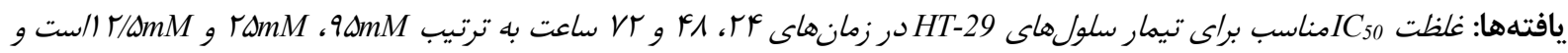

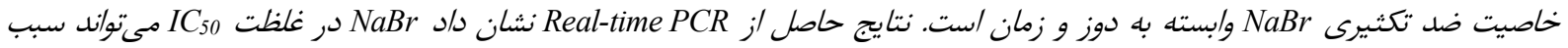

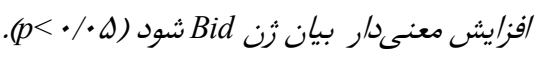

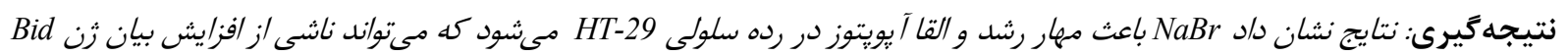

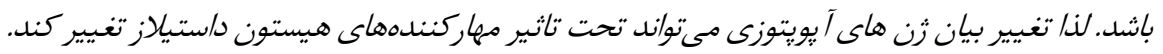

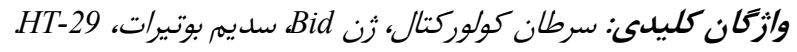

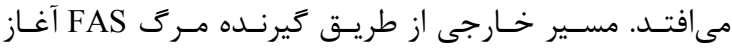

مقدمه

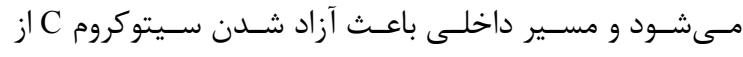

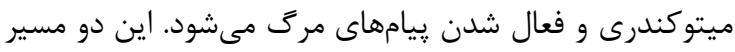

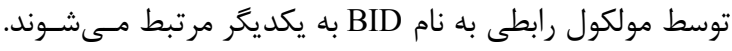

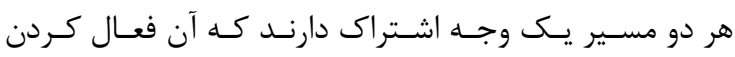

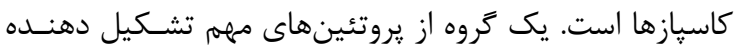

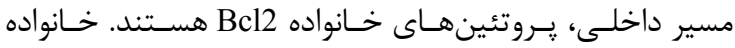

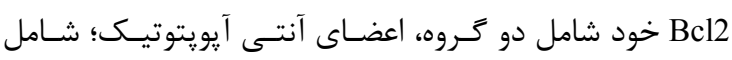
Bclx1 Bclw ، Bc12 خان Bim ، Bax ، Pid ، Buma ،Noxa Bax

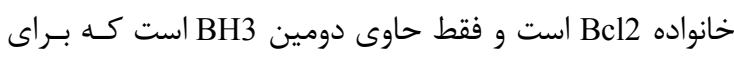

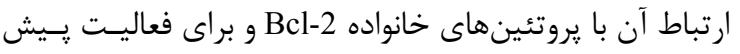

\begin{abstract}
سرطان كولون (CRC) جهارمين عامل مرك مرتبط با سـرطان

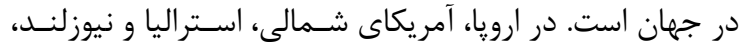

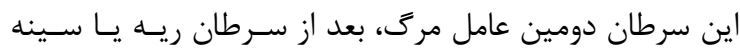

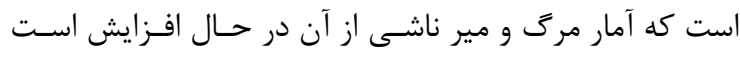

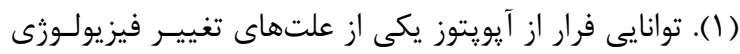

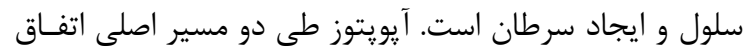

آدرس نويسنده مسئول: تهر ان، دانشكده علوم و فناورى هاى نوين، علسوم بزشكى تهـران، دانشـاه آزاد

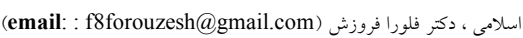
ORCID ID: 0000-0002-2747-3479 تاريخ دريافت مقاله:

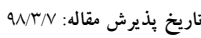




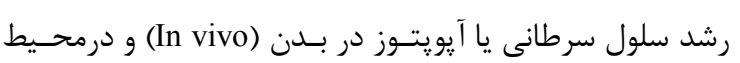

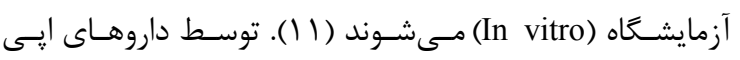

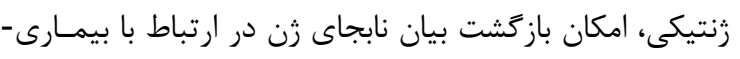

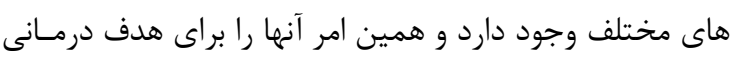

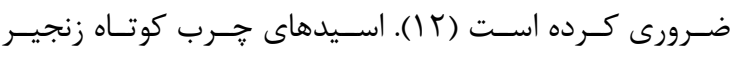

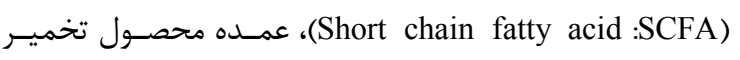

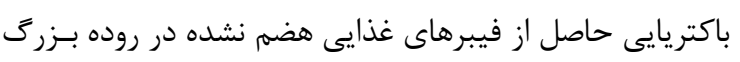

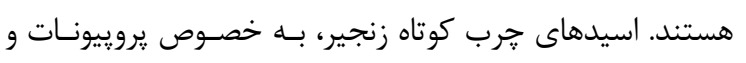

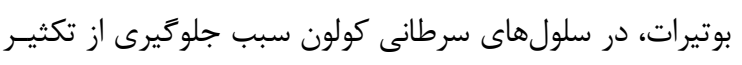

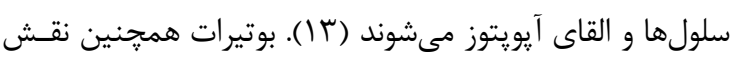

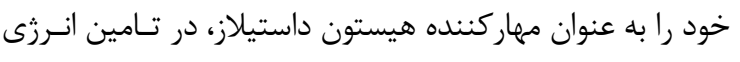

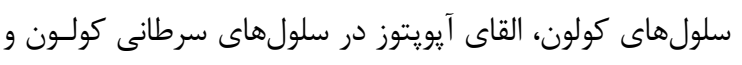

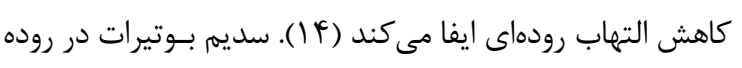

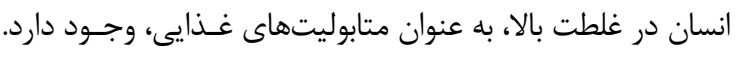

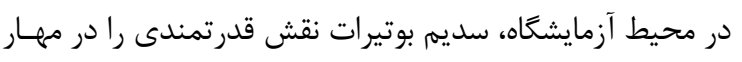

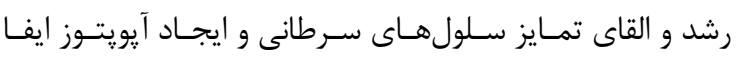

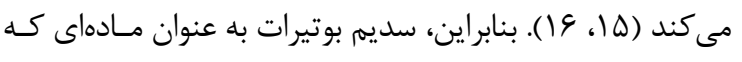

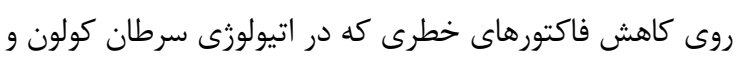

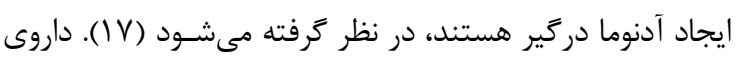

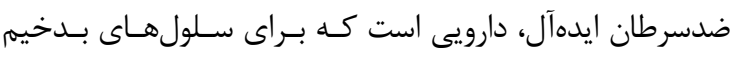

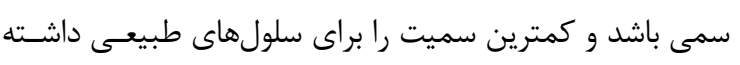

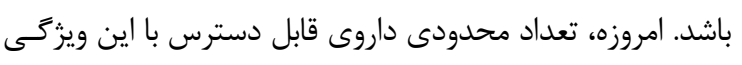

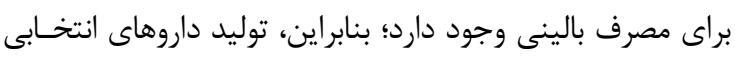

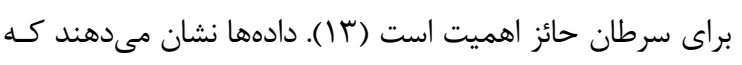

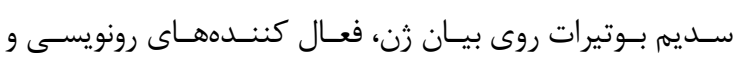

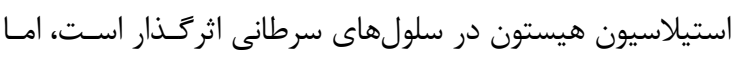

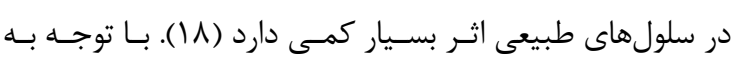

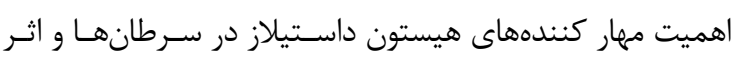

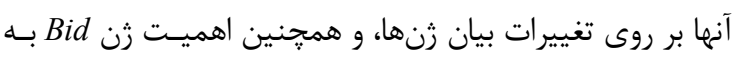

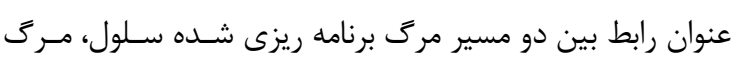

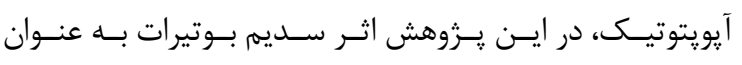

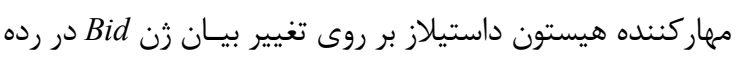

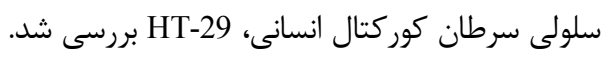

\section{مواد و روشها \\ كشت سلول}

رده سلولى HT-29 از مركز ملى ذخـاير زنتيكسى و زيسـتى ايـران

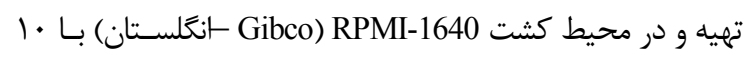

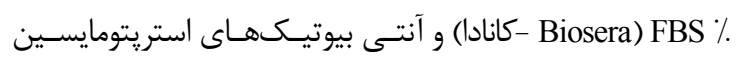

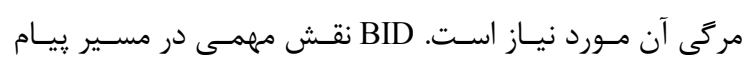

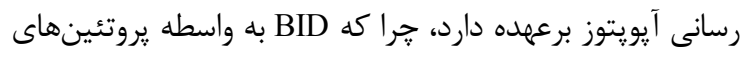

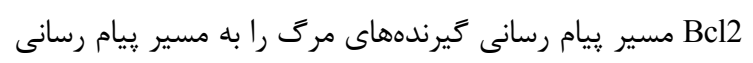

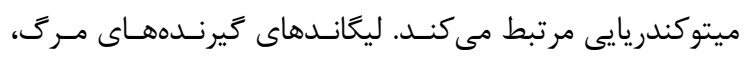

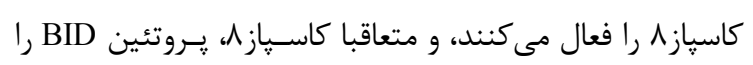

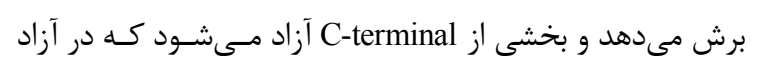

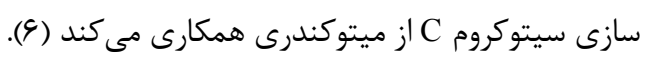

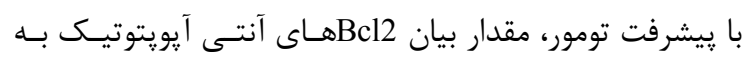

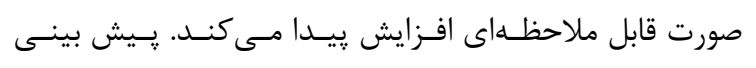

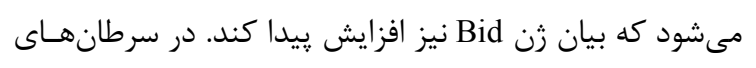

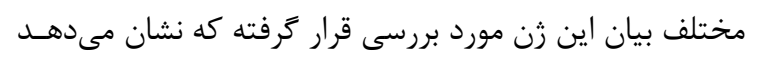

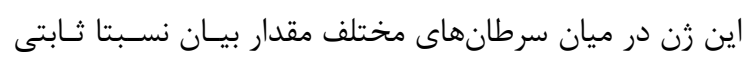

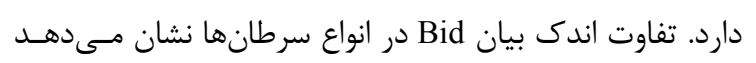

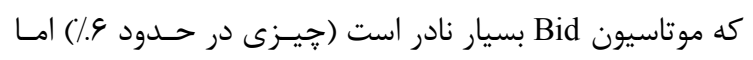

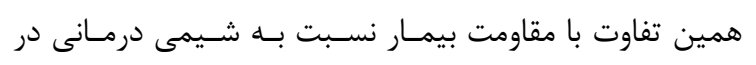

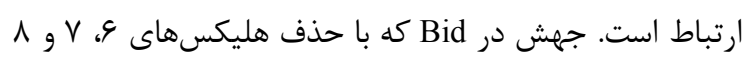

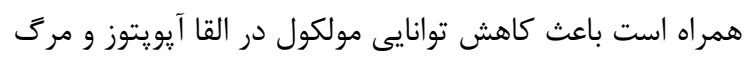

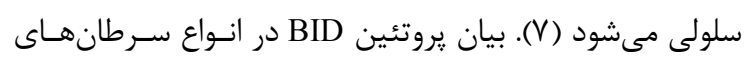

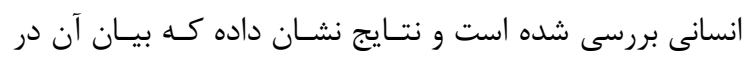

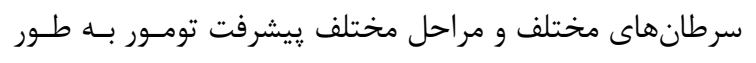
قابل ملاحظه اى متفاوت است (N).

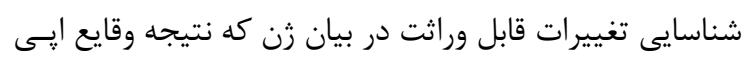

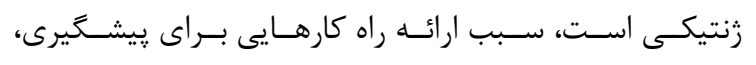
تشخيص زودرس و درمان سرطان است. استيلاسيون هيستون

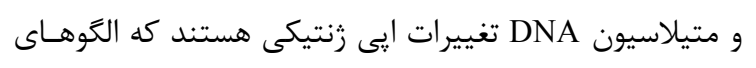

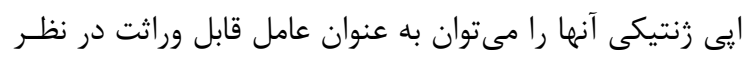

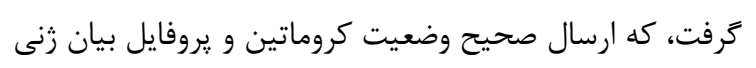

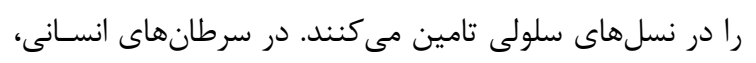

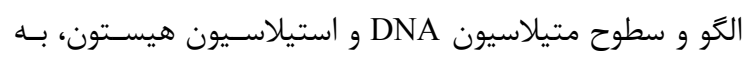

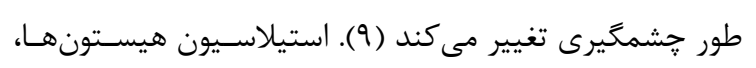

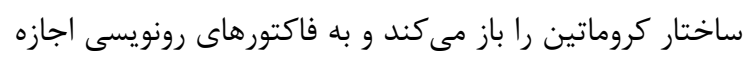

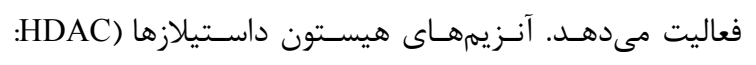
Histone deacetylase

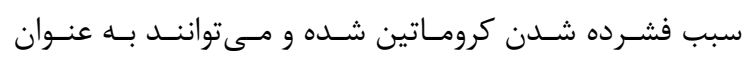

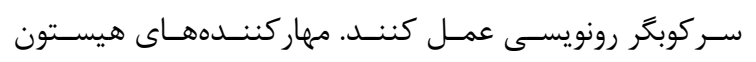

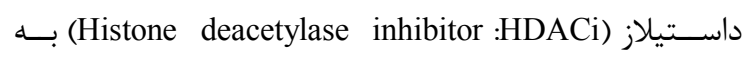
صورت انتخابى رونويسى زن را با تغيير در كروماتين و تغييرات

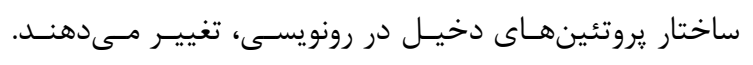

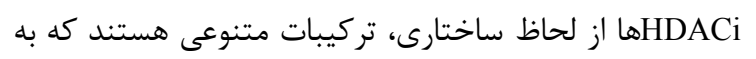

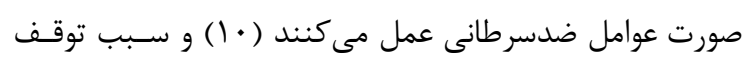


IC50 بر رشد و تكثيـر سـلولهـاى سـرطانى و تعيسين ( $9 / T \Delta M m$ MTT half maximal inhibitory concentration)

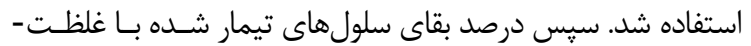
هاى مختلف سديم بوتيرات از فرمول زير محاسبه شد. درصد بقا (.): (جذب نورى رنخ توليدى در سلول هاى تيمار شده /

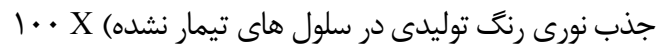

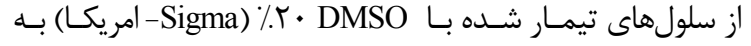

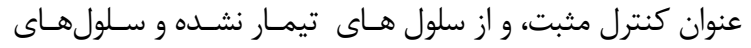

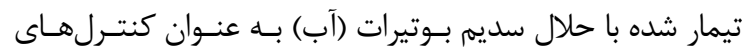

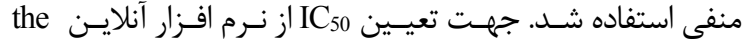
JavaScript version of PolySolve (07.20.2013)

استخراج RNA و واكنش رونويسى معكوس (RT-PCR)

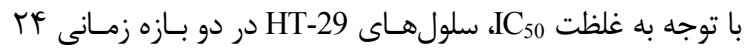

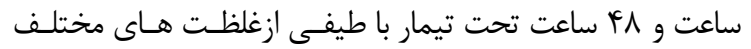

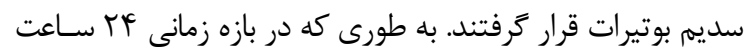

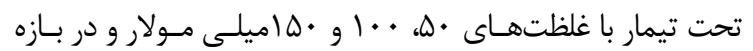

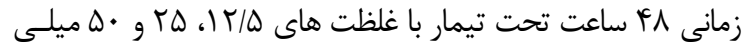

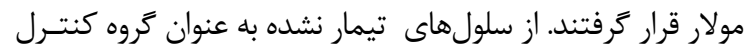

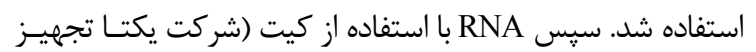

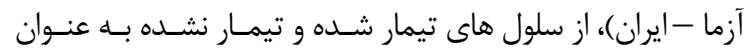

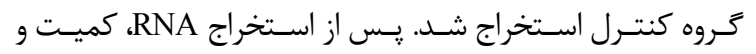
كيفيت آن به ترتيب توسط روش اسـيكتروفتومترى و الكتروفـورز

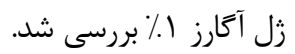
به منظور سنتز cDNA، از كيت (شركت يكتا تجهيز آزما - ايـران)

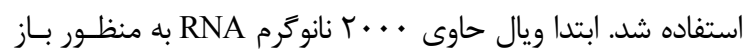

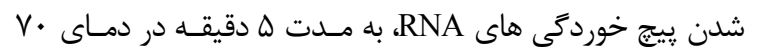

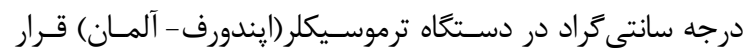

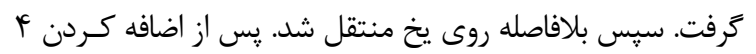

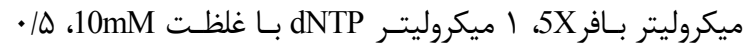

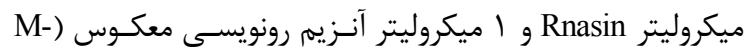

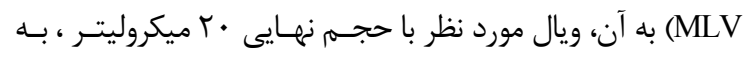

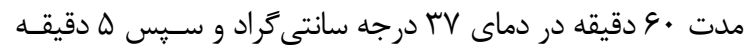

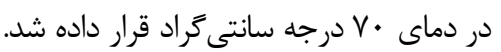

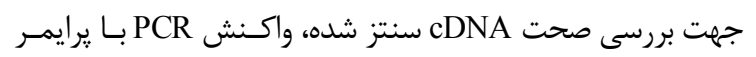

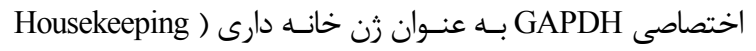

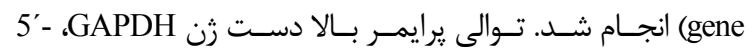
GAAGGTGAAGGTCGGAGTC-3'

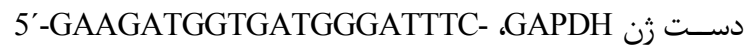
3' با كد شناسايى (Accession no)

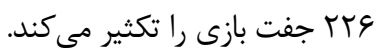

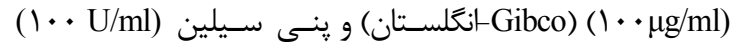
هibco)

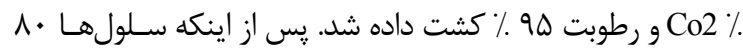

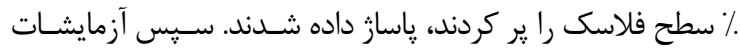

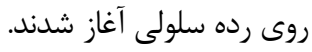

\section{شمارش و تعيين درصد سلولهاى زنده}

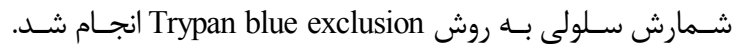

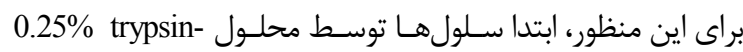
-Gibco) EDTA

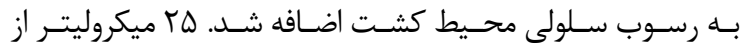

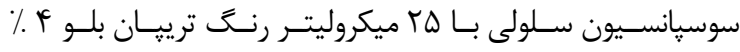

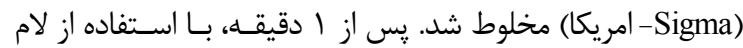
هموسيتومتر نئوبار و زيــر ميكروسـكوٍ نـورى سـلولهـا شـمرده شند. محاسبه درصد سلول هاى زنده با استفاده از فرمول زير انجام شد:

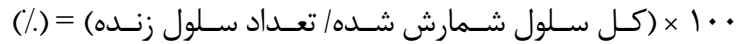

Viability سيس شمارش و تعيين درصد سلولها در هر ميلى ليتـر از رابطـهـ.

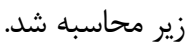
(ضريب رقت) × + • × × تعداد سلول شمارش شده در هر مربـع لام هموسيتومتر نئوبار = تعداد سلول درهر ميلى ليتر

\section{بهينه سازى تعداد سلول}

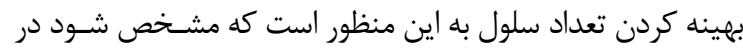

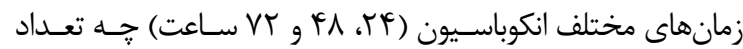

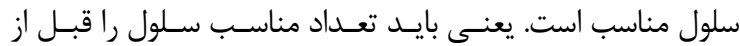
كذاشـتن تسـتهـاى تيمـار در زمـانهــاى مختلـف انكوباسـيون

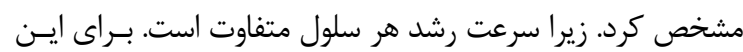

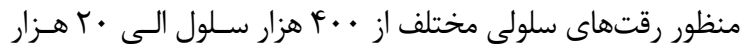

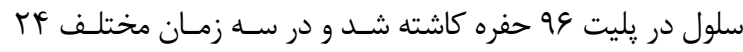

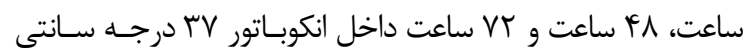

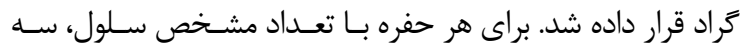

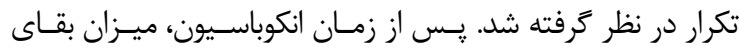

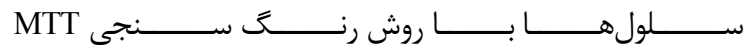
(Methylthiazolyldiphenyl-tetrazolium bromide) ارزيابى قرار ترفت.

بررسى سميت سلولى توسط تست

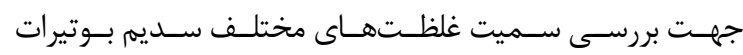

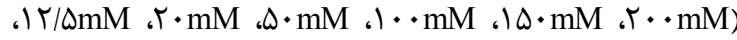




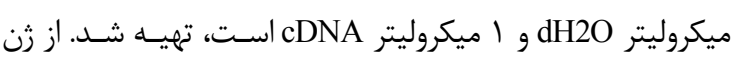

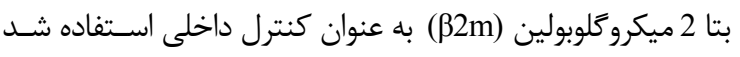

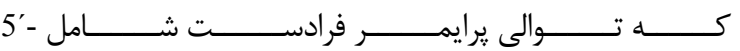
فGCTGTCTCCATGTTTGATGTATCT-3'

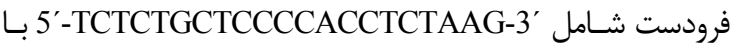

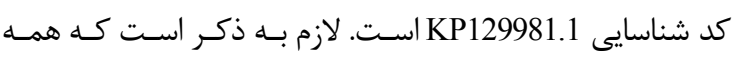

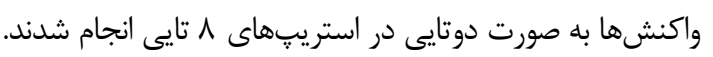

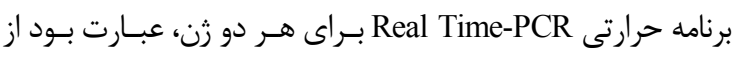

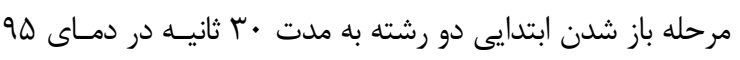

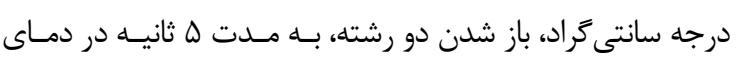

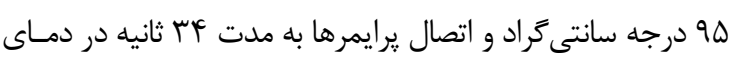

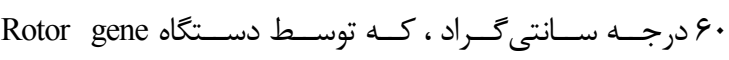

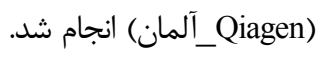
روش آمارى

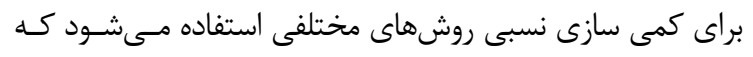

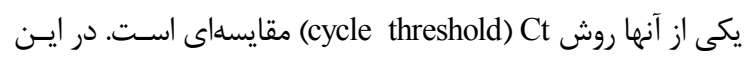

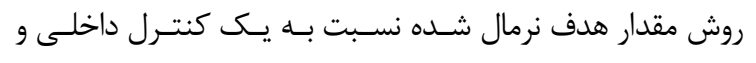

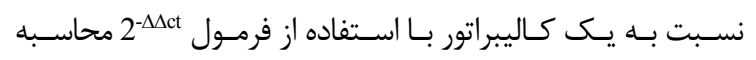

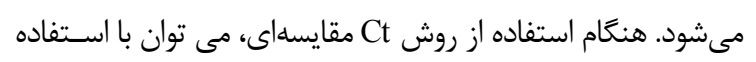

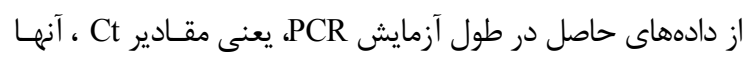

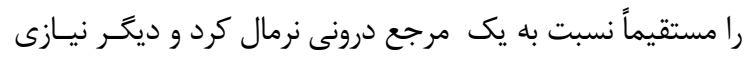

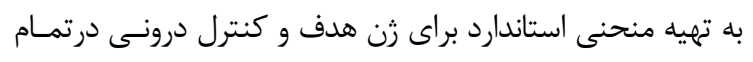
نمونههاى آزمايشى نيست.

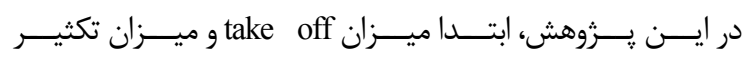
(amplification)

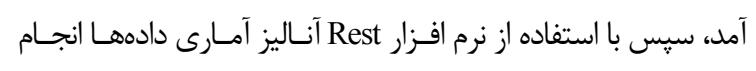
شد و سطح آمارى كمتر از هـ • • معنى الفار در نظر كرفته شد.

\section{يافتهها}

\section{بهينه كردن تعداد سلول}

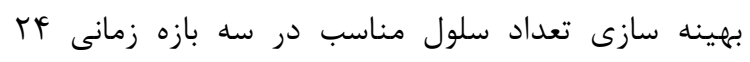

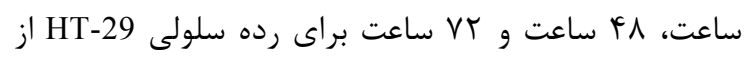

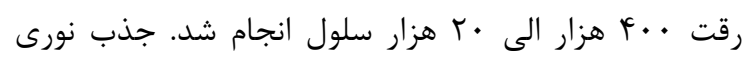

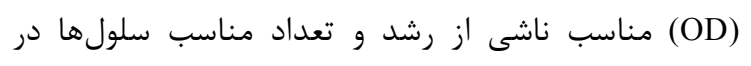

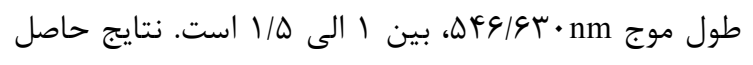

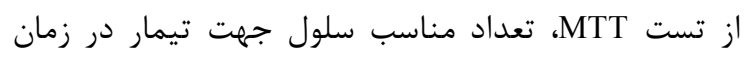

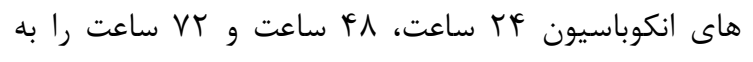
ترتيب •م هزار سلول، •ه هزار سلول و •له هزار سلول

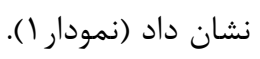

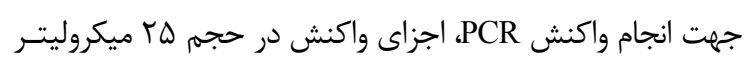

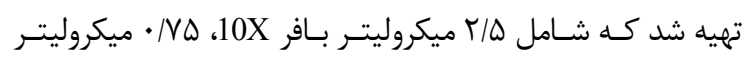

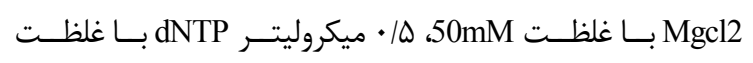
10mM

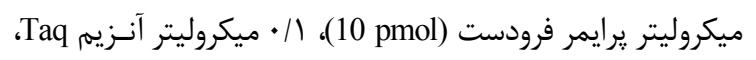

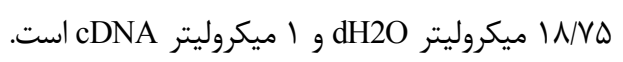

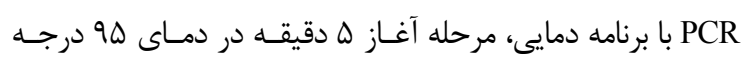

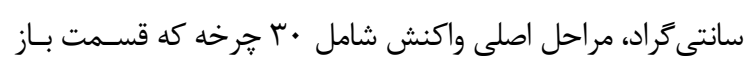

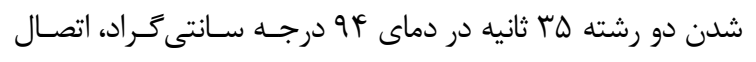

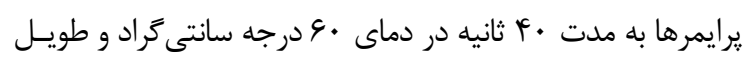

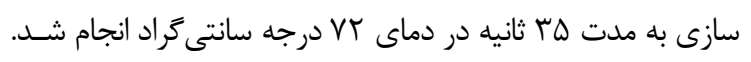

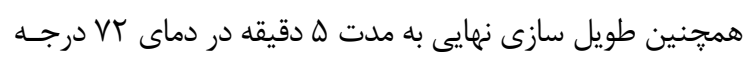

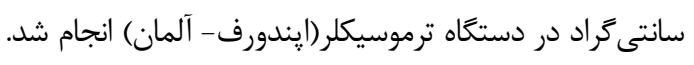
بر باسى ثن Bid با روش Conventional PCR

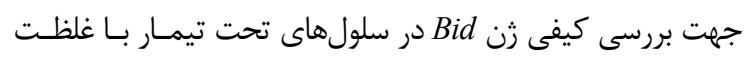

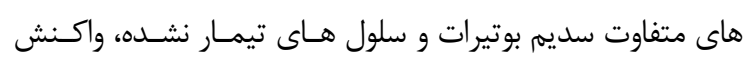

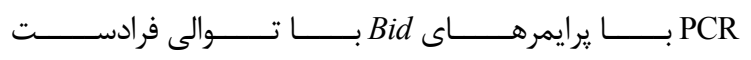
'5'_AAGTGGCTGGGCTGGCAAG_3' (5'CCAGTGGCGACAGAATCCG_3'

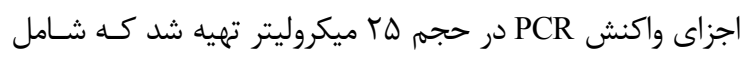

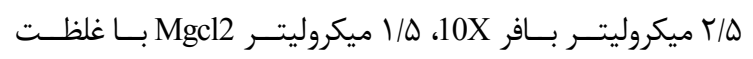

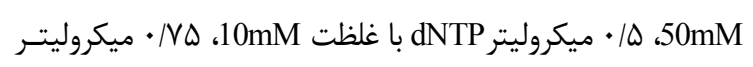

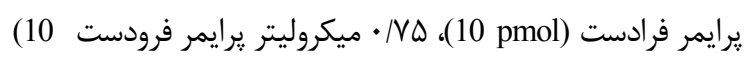

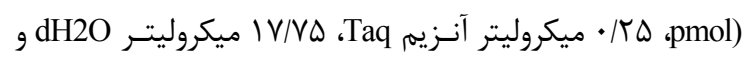

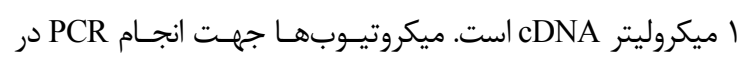

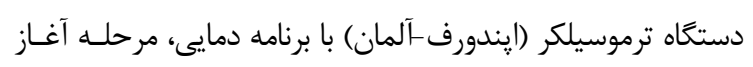

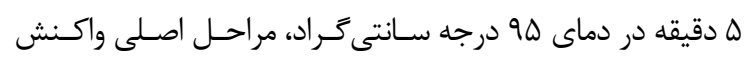

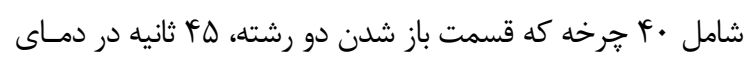

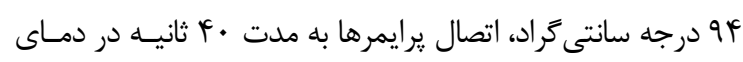

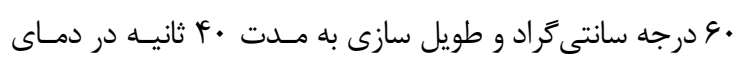

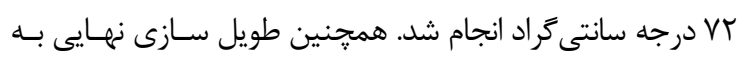

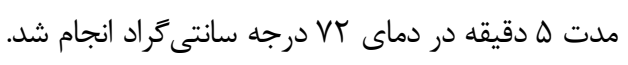

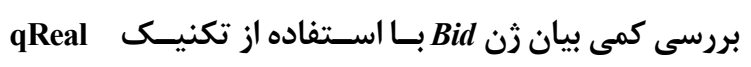
Time-PCR

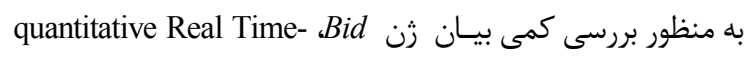

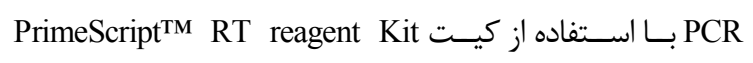

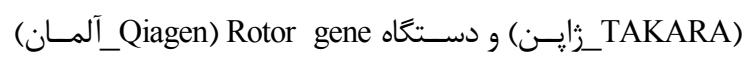

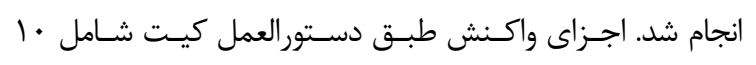

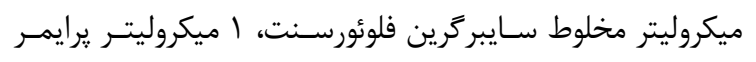

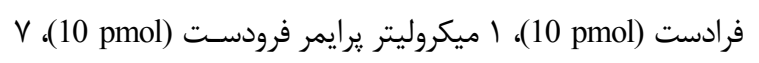


بررسى سميت سلولى غلظتهاى مختلف سديم بوتيرات

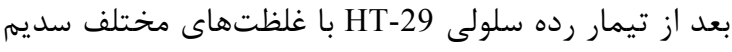
بوتيرات (r.mM 

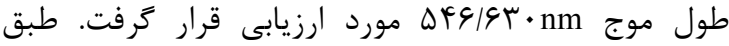

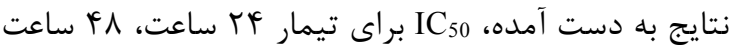

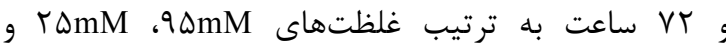
I ا تعيين شد (نمودار T). نتايج نشان داد كه افزايش غلظت سديم بوتيرات از غلظت

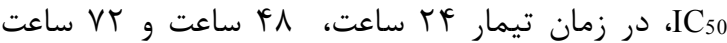
براى سلولها سمى است و باعث مركى آنها مى شود.

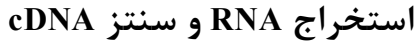
بِ از تيماررده سلولى HT-29 با غلظتهاى مختلف سديم بوتيرات (r.mM

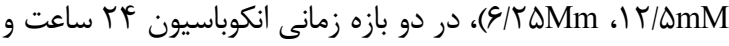

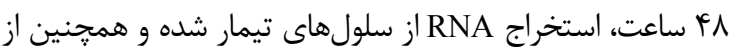
نمونه كنترل (سلولهاى تيمار نشده) صورت گرفت. نتايج بررسى إسى كيفيت و كميت RNA استخراجى توسط دستخاه اسيكتروفتومتر

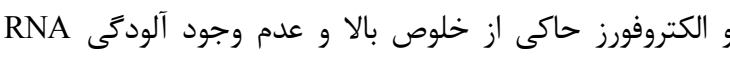

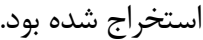
بس از استخراج RNA از نمونهها، CDNA سنتز و به منظور تائيد

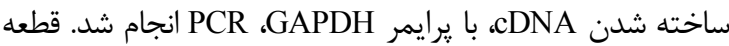
تكثير شده توسط اين يرايمرها \&Yr جفت باز است (شكل ().

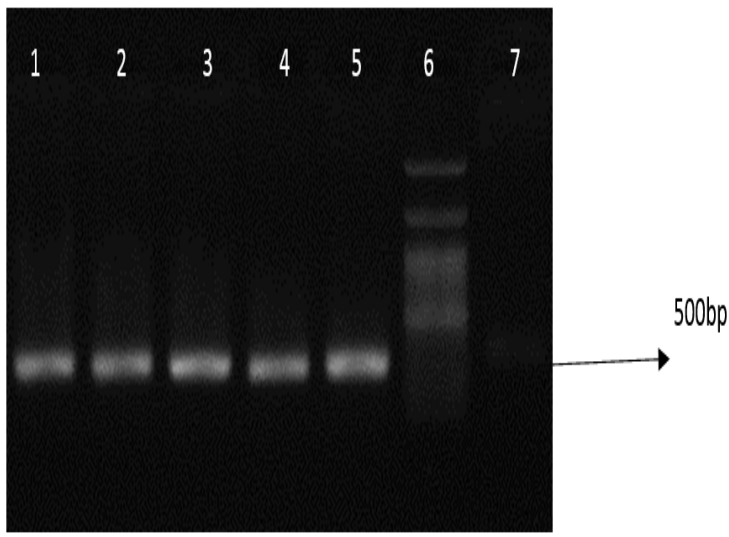

شكل ا. الكتروفورز محصول PCR زن GAPDH بر روى زل ه/1\%.

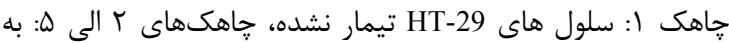

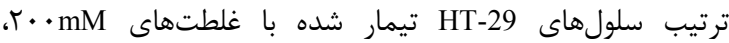

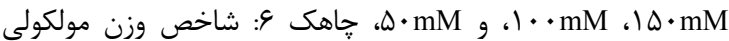

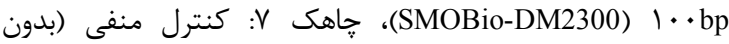
template)، اندازه قطعه تكثير شده (SY ج جفت باز است.
HT-29

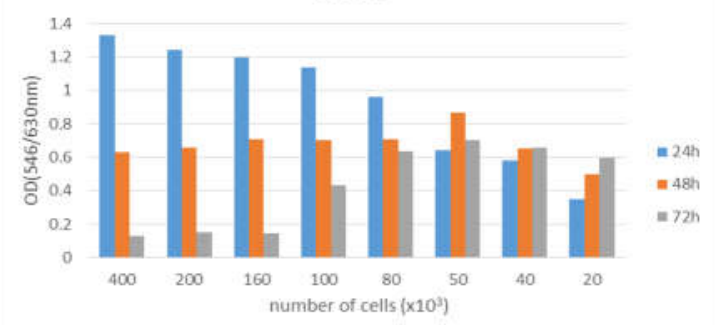

نمودار I. بهينه سازى تعداد سلول HT-29 جهت تيمار در زمان

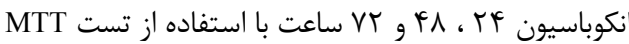
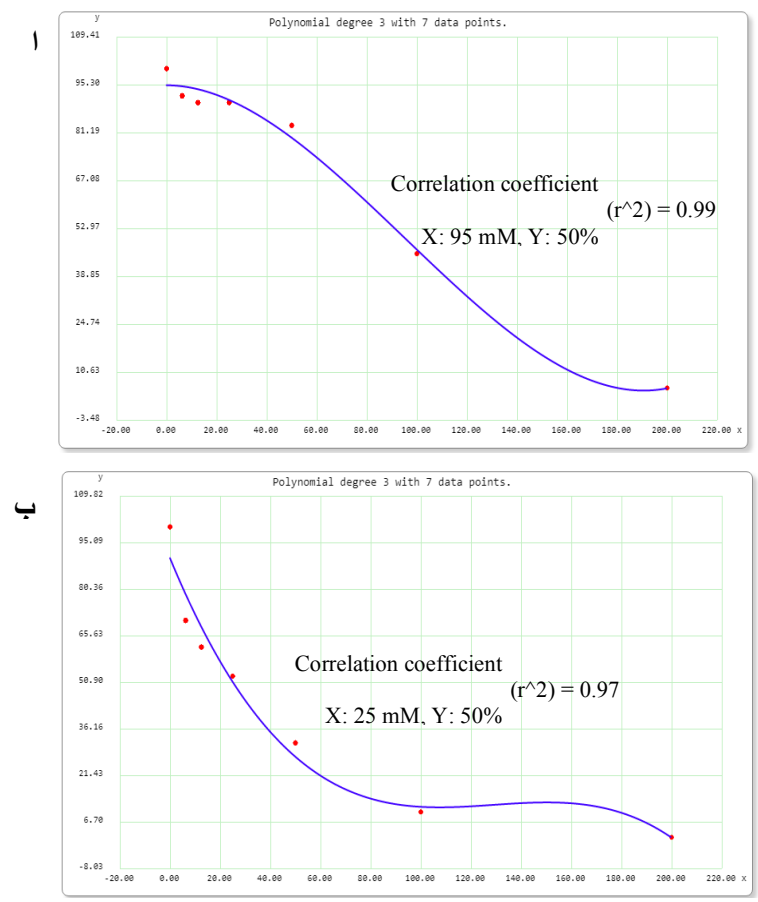

ج

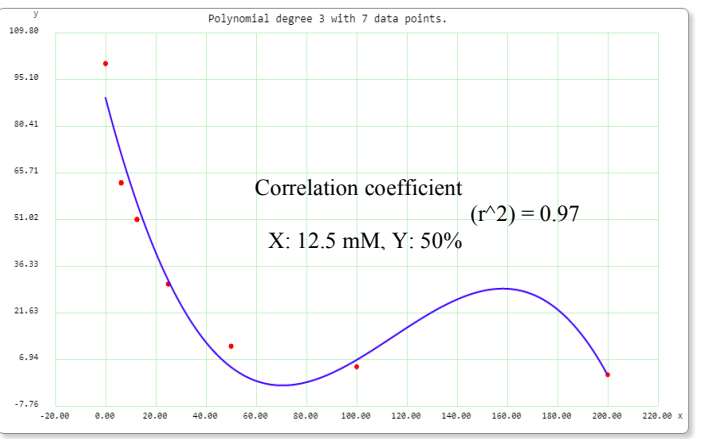

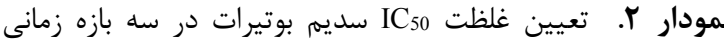

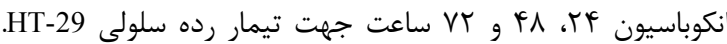

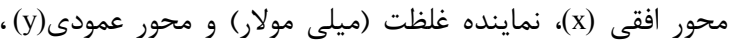

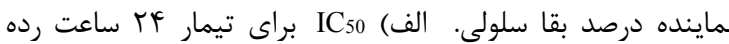

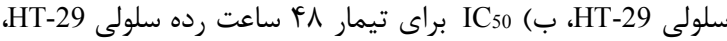

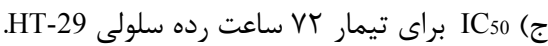


بر رسى كمى تغيير بيان زن Bid

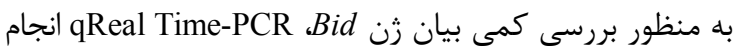

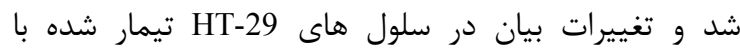
غلظتهاى مختلف سديم بوتيرات و سلولهاى HT-29 تيمار

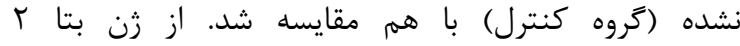
ميكروكلوبولين (م2m) به عنوان كنترل داخلى استفاده شد.

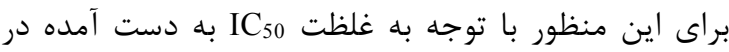

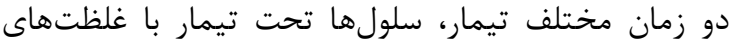
مختلف سديم بوتيرات قرار گرفتند. به طورى كه در بازه

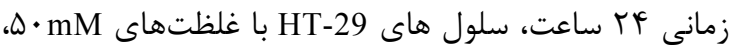

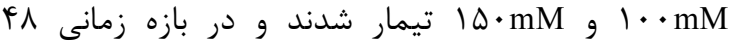
ساعت، تحت تيمار با غلظتهاى

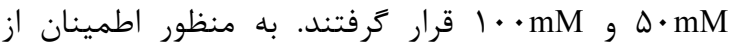

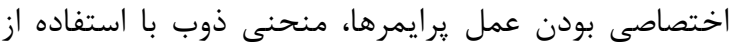
نرم افزار Rotor gene به دست آمدي نتايج حاصل از بررسى تغيير كمى بيان زن Bid نشان داد

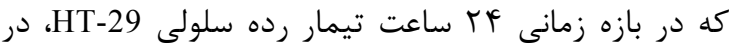

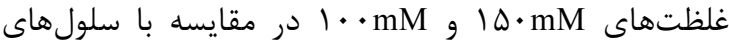

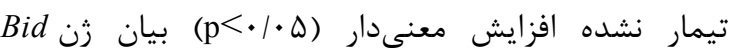

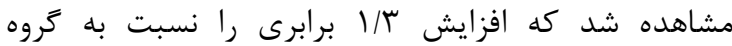
كنترل نشان داد. با توجه به نتايج حاصل در اين يزوهش، غلظت IC براى رده سلولى HT-29 در بازه زمانى تيمار آ

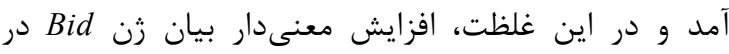
مقايسه با كروه كنترل مشاهده شد (نمودار س).

\section{HT-29}

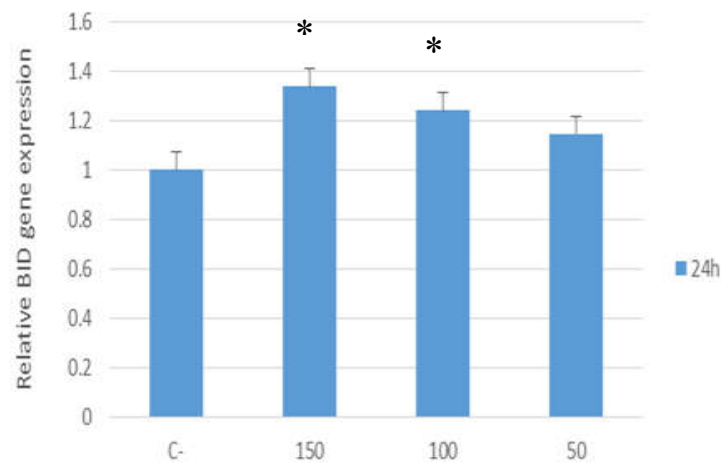
sodium butyrate concentration (mM)

نمودار سّ. مقايسه ميزان بيان زن Bid در رده سلولى HT-29 تيمار

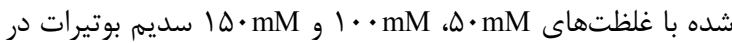

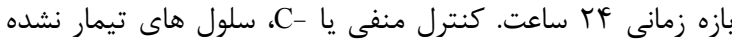

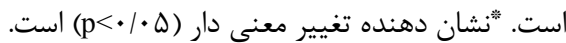

بررسى زن Bid با روش Conventional PCR

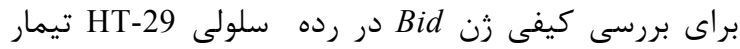
شده با غلظتهاى مختلف سديم بوتيرات و سلولهاى ترنى تيمار

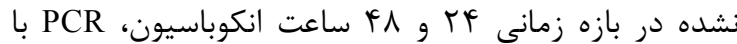
يرايمر Bid انجام شد و براى مشاهده نتيجه، محصول آنها بر روى زل آكارز ه/ (1 باركيرى شد. قطعه زن تكثير شدهام

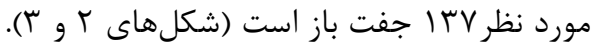

\section{$\begin{array}{lllllll}1 & 2 & 3 & 4 & 5 & 6 & 7\end{array}$}

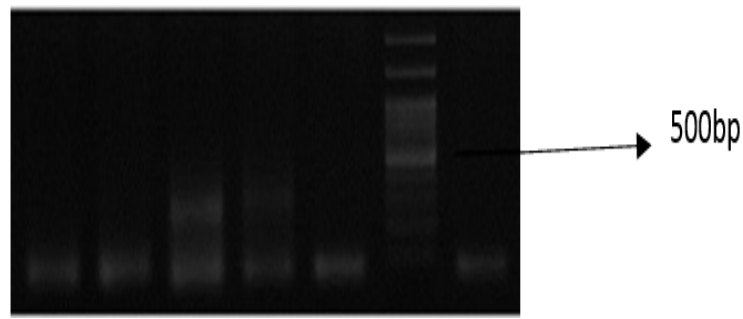

شكل r. الكتروفورز محصول PCR زن Bid بر روى زل ه/ (\% زمان

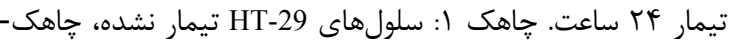

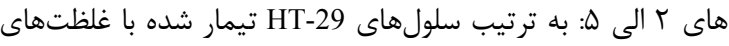

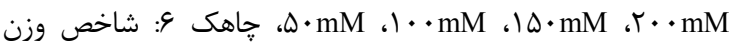

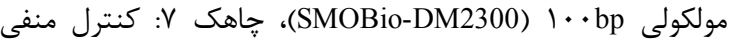
(بدون template) و باندى كه در קاهك كنترل منفى مشاهده مى شود مربوط به يرايمر دايمر است. اندازه قطعه تكثير شده و مورد

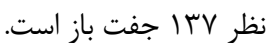

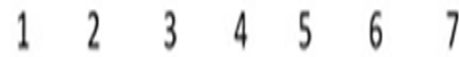

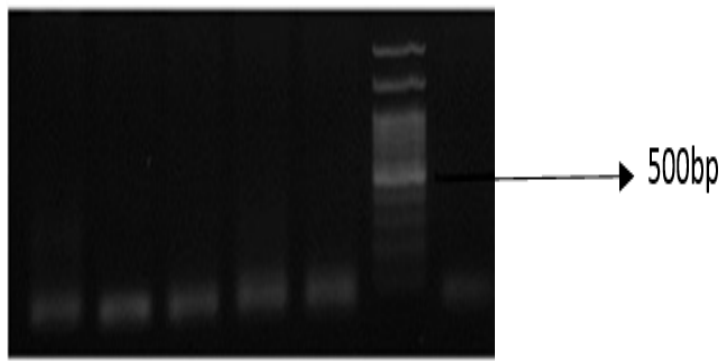

شكل r. الكتروفورز محصول PCR زن Bid بر روى زل ه/ 1/\% زمان

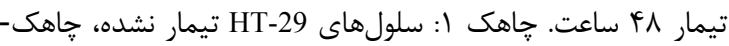

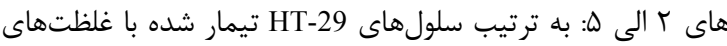

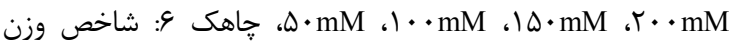

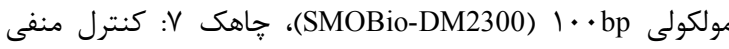

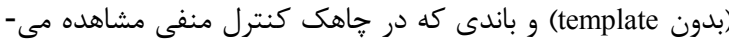
شود مربوط به يرايمر دايمر است. اندازه قطعه تكثير شده و موري مورد نظر VIr إ جفت باز است. 
تكثير سلولى به عنوان بخشى از فرآيند طبيعى تكامل ايفاى

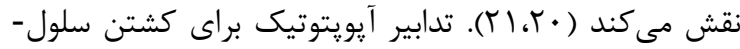
هاى تومورى، شامل القاى مستقيم مولكولهاى يروآيويتوتيك آني

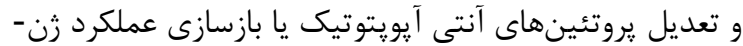

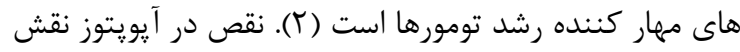
مهمى در تشكيل تومورها و ايجاد نئويلازى بازى مى كند و به به هم خوردن تنظيم آن باعث مقاومت به شيمى درمانى و و يرتو درمانى مىشود. اين روند ممكن است باعث افزايش متاستاز

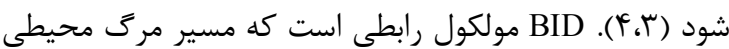
را به آيويتوز مركزى (ميتوكندريايى) مرتبط مى كند (Tr). (Y).

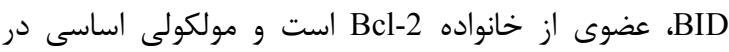

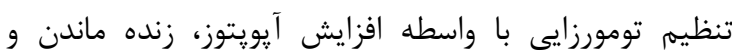
تكثير است. با توجه به اين عملكردهاى متنوع BID، اين ائ مولكول در קاسخ به استرس دو نقش متفاوت دارد (ه). بيان

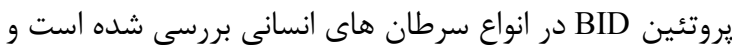
نتايج نشان داده كه بيان آن در سرطان هاى مختلف و وركان مراحل مختلف بِيشرفت تومور بطور قابل جشمخيرى متفاوت است. در دران

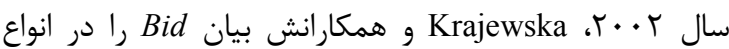
متفاوت سرطانهاى انسانى به وسيله ايمونوهيستوشيميايى بررسى كردند و نشان دادند در سرطانهاى مختلف و مراحل

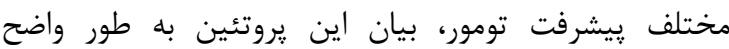
متفاوت است. به طورى كه در آدنوكارسينوماى اوليه كولوركتال افزايش بيان معنىدار در مقايسه با ابیىتليوم نرمال

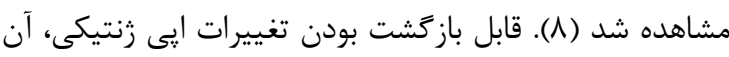
را به عنوان راهى بالقوه براى درمان سرطان معرفى مى كند. تعدادى از تركيباتى كه مورد اهداف درمانى هستند، آنزيمهايى هستند كه استيلاسيون هيستون، متيلاسيون هيستون و دئياني متيلاسيون DNA را تنظيم مى كنند، كه در بدخيمىهاى هئل هماتولوزيكى و تومورهاى سخت، اثرقابل توجهى دارند (بآ).

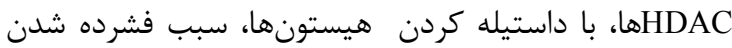
كروماتين شده و مىتوانند به عنوان سركوبكر رونويسى عمل

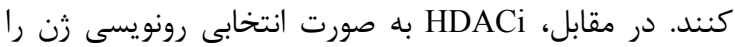
توسط تغيير در كروماتين و تغييرات ساختار يروتئينهاى دخيل در رونويسى، تغيير مى دهند (TY). سديم بوتيرات اسيد جرب اشباع جهار كربنه است كه در ديواره روده انسان در درئر غلطت بالا، حاصل از متابوليتهاى غذا، وجود دارد و به عنوان HDACi است (צا). در اين يزوهش، اثر سديم بوتيرات بر روى تغيير

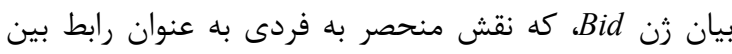

نتايج حاصل از بررسى تغيير كمى بيان زن Bid در بازه

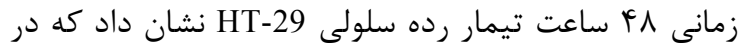
غلظت mM · إفزايش بيان در مقايسه با سلولهاى تيمار نشده، معنى دار (ه•|•>م) بود، به طورى كه افزايش بيان

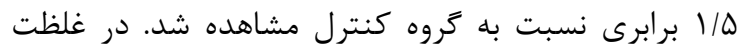
DM دا در مقايسه با سلولهاى تيمار نشده، كاهش بيان

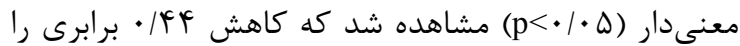
نسبت به كروه كنترل نشان داد (نمودار \&).

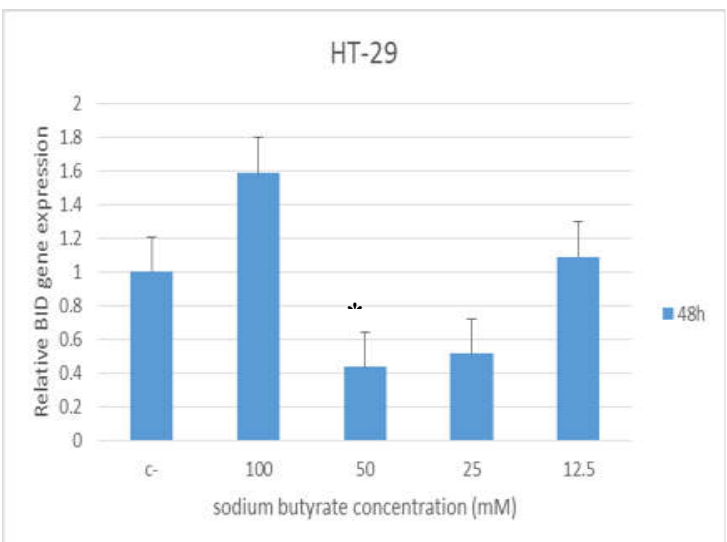

نمودار f. مقايسه ميزان بيان زن Bid در رده سلولى HT-29 تيمار

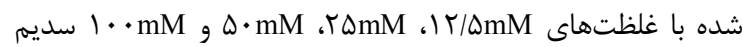

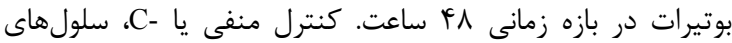

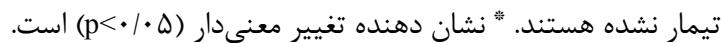

با توجه به نتايج حاصل از اين يزوهش، غلظت IC براي

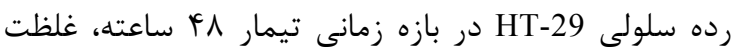

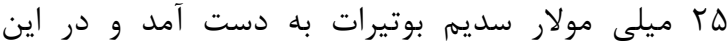

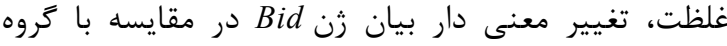

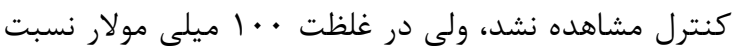
به كروه كنترل، افزايش معنى دارى مشاهده شد.

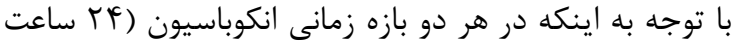

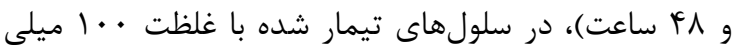
مولار افزايش بيان زن Bid در مقايسه با سلولهاى تيمار نشده مشاهده شد به نظر مىرسد اين غلظت مئ توتواند دوز

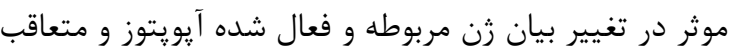
آن مرى سلولهاى سرطانى باشد.

\section{بحث}

توانايى فرار از آيويتوز يكى از علتهاى تغيير فيزيولوزى سلول و ايجاد سرطان است. آيويتوز براى كنترل تعداد سلولها و وائاي 
در بررسى وجود و عدم وجود زن Bid به روش PCR در رده

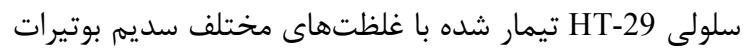
در زمان تيمار FF ساعت، مشخص شد كه در غلظتهاى

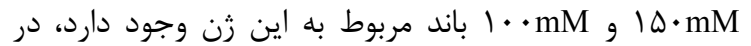

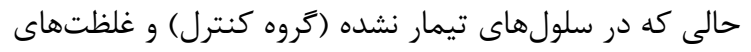

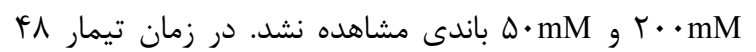

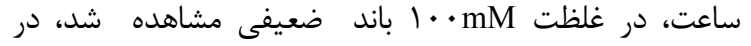

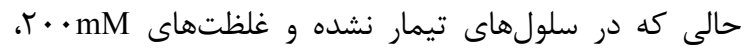

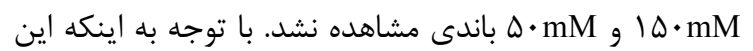

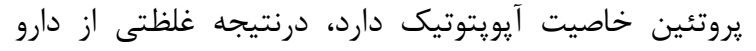

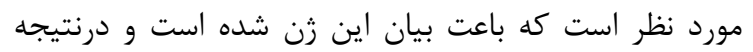

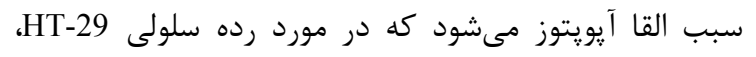

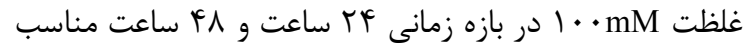
است. نتايج حاصل از اين تحقيق براى اولين بار زَزارش شده

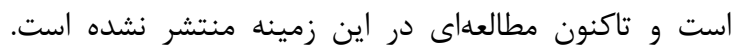

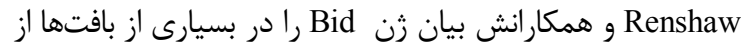

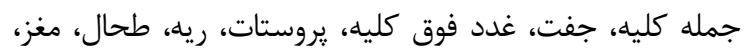

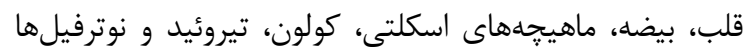

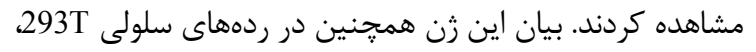
(9) Cos،HeLa،Jurkat در بررسى تغييرات كمى بيان زن Bid در رده سلولى

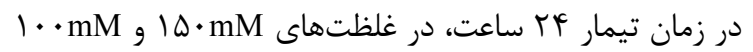

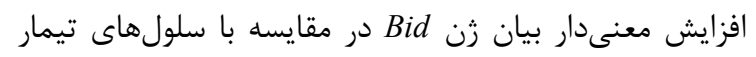

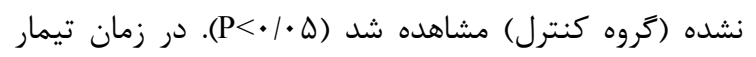

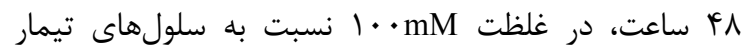

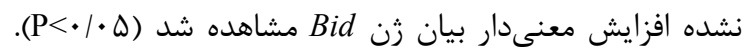

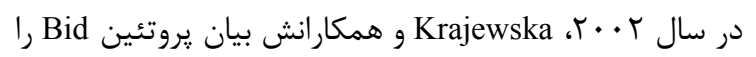

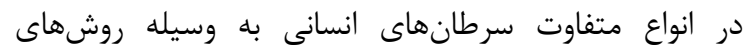

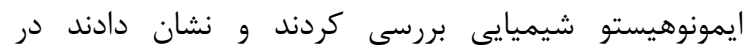

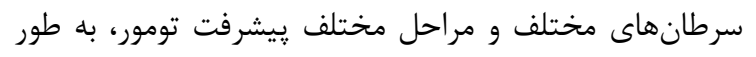

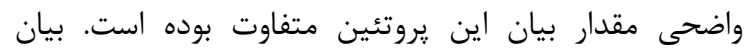

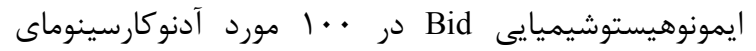

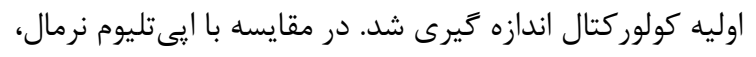

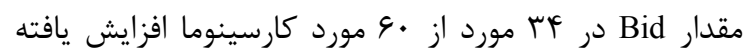

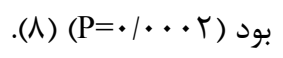

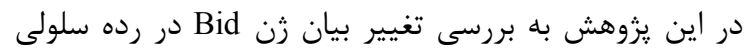

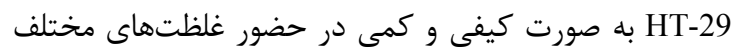
سديم بوتيرات به عنوان يك HDACi ير برداخته شد.

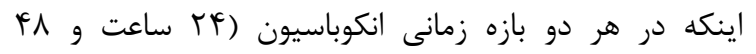

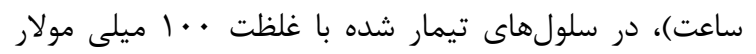

مسير خارجى و مسير داخلى آيويتوز دارد، در رده سلولى سرطان كولور كتال انسانى

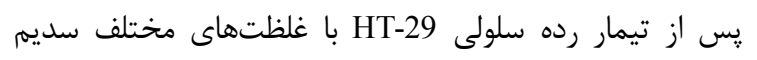

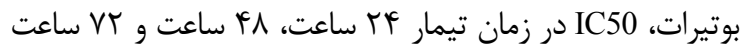

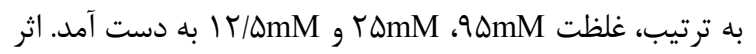
ضد تكثيرى سديم بوتيرات وابسته به دوز و زمان تيمار است. زيرا

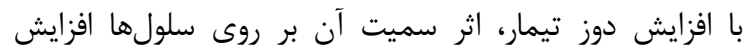

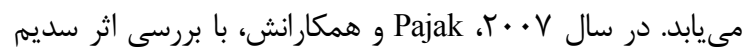

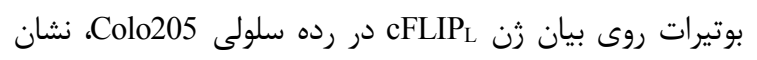

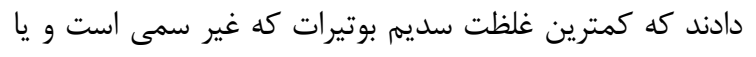

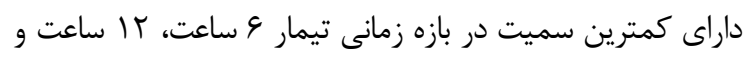

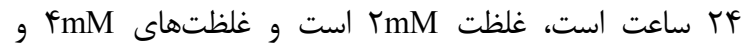

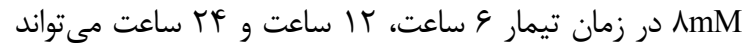

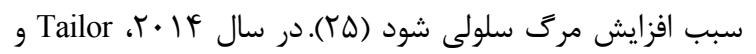

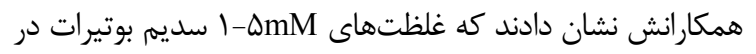

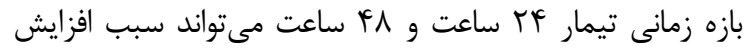

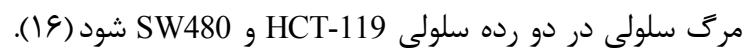

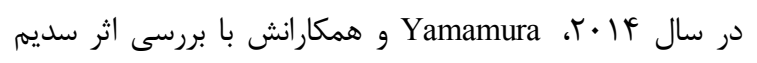

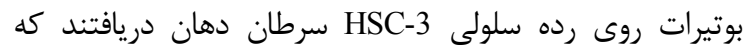

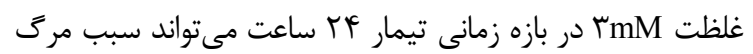

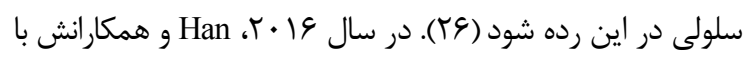
بررسى اثر سديم بوتيرات روى سلولهاى سرطانى مثانه، دريافتند

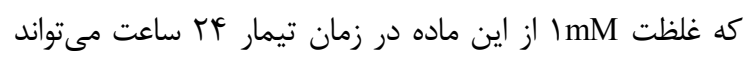

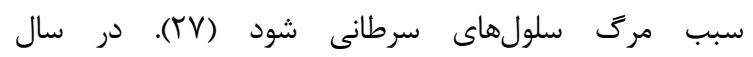

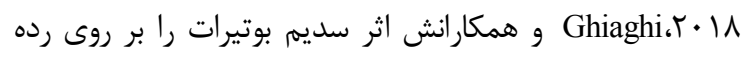

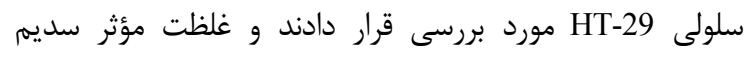

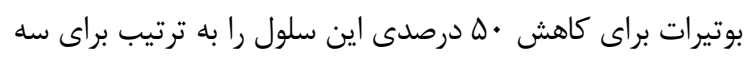

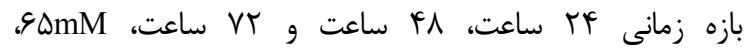

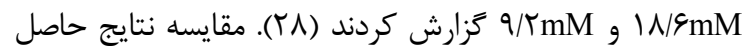

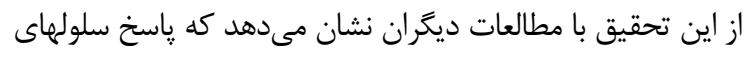

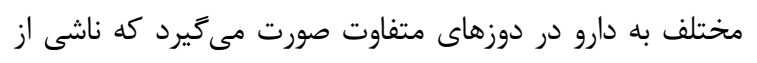

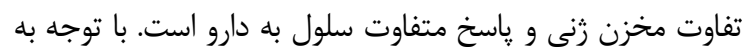

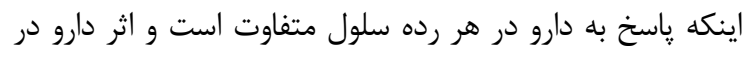

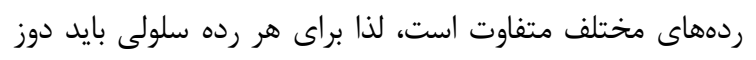

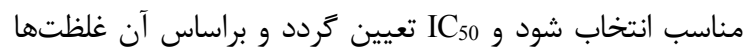
جهت تيمار دارويى انتخاب شود.

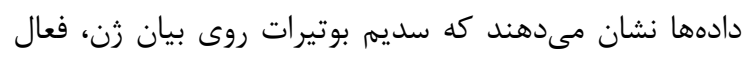

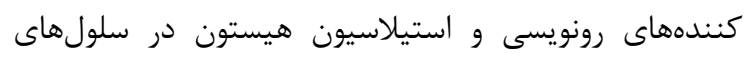

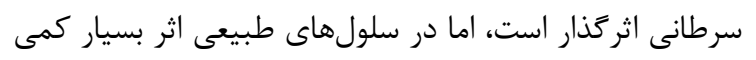

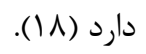




\section{تشكر و قدردانى}

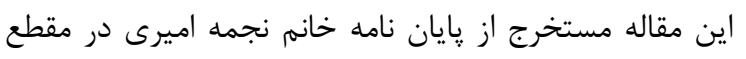

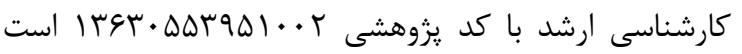

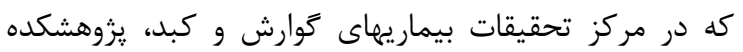

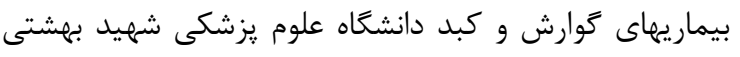

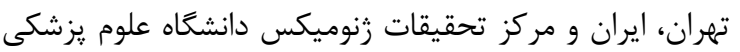

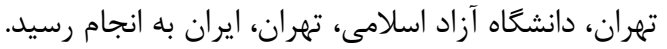

افزايش بيان زن Bid در مقايسه با سلول هاى تيمار نشده به

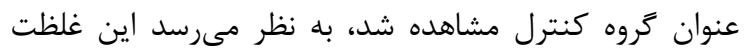
مىتواند دوز موثر در تغيير بيان زن مربون مناه

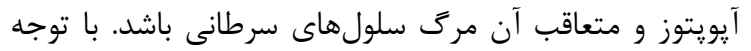

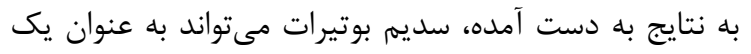

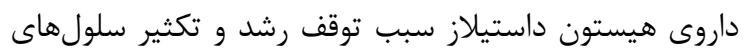
سرطانى از طريق اثر بر بيان زن آيويتوتيك شود.

\section{REFERENCES}

1. Hijova E, Chmelarova A. Short chain fatty acids and colonic health. Bratisl Lek Listy 2007;108:354.

2. Pecorino L, Editor. Molecular biology of cancer: mechanisms, targets, and therapeutics. $3^{\text {rd }}$ ed. UK: Oxford University Press; 2012.

3. Wong RS. Apoptosis in cancer: from pathogenesis to treatment. J Exp Clin Cancer Res 2011;30:87.

4. Lowe SW, Lin AW. Apoptosis in cancer. Carcinogenesis 2000;21:485-95.

5. Korsmeyer SJ, Wei MC, Saito MT, Weiler S, Oh KJ, Schlesinger PH. Pro-apoptotic cascade activates BID, which oligomerizes BAK or BAX into pores that result in the release of cytochrome c. Cell Death Differ 2000;7:1166.

6. Renshaw SA, Dempsey CE, Barnes FA, Bagstaff SM, Dower SK, Bingle CD, et al. Three novel Bid proteins generated by alternative splicing of the human Bid gene. J Biol Chem 2004;279:2846-55.

7. Lee JH, Soung YH, Lee JW, Park WS, Kim SY, Cho YG, et al. Inactivating mutation of the pro-apoptotic gene BID in gastric cancer. J Pathol 2004;202:439-45.

8. Krajewska M, Zapata JM, Meinhold-Heerlein I, Hedayat H, Monks A, Bettendorf H, et al. Expression of Bcl-2 family member Bid in normal and malignant tissues. Neoplasia 2002;4:129-40.

9. Vaissière T, Sawan C, Herceg Z. Epigenetic interplay between histone modifications and DNA methylation in gene silencing. Mutat Res 2008;659:40-8.

10. Karamouzis MV, Konstantinopoulos PA, Papavassiliou AG. The activator protein-1 transcription factor in respiratory epithelium carcinogenesis. Mol Cancer Res 2007;5:109-20.

11. Gui CY, Ngo L, Xu WS, Richon VM, Marks PA. Histone deacetylase (HDAC) inhibitor activation of p21WAF1 involves changes in promoter-associated proteins, including HDAC1. Proc Natl Acad Sci USA 2004;101:1241-6.

12. Szyf M. Epigenetics, DNA methylation, and chromatin modifying drugs. Annu Rev Pharmacol Toxicol 2009:25;49.

13. Yagi A, Byung PY. Putative anti-cancer action of Aloe vera via butyrate fermentation. J Gastroenterol Hepatol 2017:21;6:2419-24.

14. McNabney S, Henagan T. Short chain fatty acids in the colon and peripheral tissues: a focus on butyrate, colon cancer, obesity and insulin resistance. J Nutr 2017;9:1348.

15. Avivi-Green C, Polak-Charcon S, Madar Z, Schwartz B. Different molecular events account for butyrate-induced apoptosis in two human colon cancer cell lines. J Nutr 2002;132:1812-8.

16. Tailor D, Hahm ER, Kale RK, Singh SV, Singh RP. Sodium butyrate induces DRP1-mediated mitochondrial fusion and apoptosis in human colorectal cancer cells. Mitochondrion 2014;16:55-64.

17. Kotunia A, Wolinski J, Laubitz D, Jurkowska M, Rome V, Guilloteau P, et al. Effect of sodium butyrate on the small intestine development in neonatal piglets feed by artificial sow. J Physiol Pharmacol 2004;55:59-68.

18. Paskova L, Trtkova KS, Fialova B, Benedikova A, Langova K, Kolar Z. Different effect of sodium butyrate on cancer and normal prostate cells. Toxicol In Vitro 2013;27:1489-95.

19. Sadat Kia F, Nazemalhosseini-Mojarad E, Forouzesh F. A quantitative investigation of the Bid gene expression in biopsies from colorectal adenomas. J Dent (Tehran) 2018;76:120-8.

20. Hengartner MO. The biochemistry of apoptosis. Nature 2000;407:770.

21. Evan GI, Vousden KH. Proliferation, cell cycle and apoptosis in cancer. Nature 2001;411:342.

22. Yin XM. Bid, a BH3-only multi-functional molecule, is at the cross road of life and death. Gene 2006;369:7-19. 
23. Ellis L, Atadja PW, Johnstone RW. Epigenetics in cancer: targeting chromatin modifications. Mol Cancer Ther 2009:1535-7163.

24. Dokmanovic M, Marks PA. Prospects: histone deacetylase inhibitors. J Cell Biochem 2005;96:293-304.

25. Pajak B, Orzechowski A, Gajkowska B. Molecular basis of sodium butyrate-dependent proapoptotic activity in cancer cells. Adv Med Sci 2007;52.

26. Yamamura T, Matsumoto N, Matsue Y, Okudera M, Nishikawa Y, Abiko Y, et al. Sodium butyrate, a histone deacetylase inhibitor, regulates Lymphangiogenic factors in oral cancer cell line HSC-3. Anticancer Res 2014;34:17018 .

27. Han MH, Choi YH. Effects of sodium butyrate, a histone deacetylase inhibitor, on TRAIL-mediated apoptosis in human bladder cancer cells. Life Sci 2016;26:431-8.

28. Ghiaghi M, Forouzesh F, Rahimi H. Effect of sodium butyrate on LHX1 mRNA expression as a transcription factor of HDAC8 in human colorectal cancer cell lines. Avicenna J Med Biotechnol 2019;11:23-28. 